\title{
Tamarind tree seedlings in protected environments and substrate
}

\section{Anne Karoline da Silva ${ }^{1}$, Edilson Costa ${ }^{2}$, Thayla Morandi Ridolfi de Carvalho Curi ${ }^{3}$, Josiane Souza Salles ${ }^{4}$, Flávio Ferreira da Silva Binotti ${ }^{2}$, Eliana Duarte Cardoso Binotti², Gustavo Haralampidou da Costa Vieira², Tiago Zoz ${ }^{2}$}

${ }^{1}$ Universidade Estadual de Mato Grosso do Sul, Unidade Universitária de Aquidauana, Aquidauana, Mato Grosso do Sul, Brasil. E-mail: anneagronomia@hotmail.com

${ }^{2}$ Universidade Estadual de Mato Grosso do Sul, Unidade Universitária de Cassilândia, Cassilândia, Mato Grosso do Sul, Brasil. E-mail: edilson.costa@uems.br, binotti@uems.br,dclia78@yahoo.com.br,gcv@uems.br, zoz@uems.br

${ }^{3}$ Universidade Anhanguera, Campinas, São Paulo, Brasil. E-mail: thaylamrcarvalho@ hotmail.com

${ }^{4}$ Universidade Estadual Paulista "Júlio de Mesquita Filho", Campus Ilha Solteira, Ilha Solteira, São Paulo, Brasil. E-mail: josi_souzasalles@hotmail.com

Received: 18/04/2020; Accepted: 20/05/2020.

\begin{abstract}
This study aimed to evaluate the formation of tamarind tree seedlings in different protected environments and substrates. Five protected environments were used and substrates using combinations of different proportions of humus, cattle manure, vermiculite, and cassava stems. The environments with screens and the environments with polyethylene films were conducive to the emergence of the tamarind seedlings. All the substrates presented adequate conditions for the emergence of seedlings in these environments. The environment covered with bacuri straw was not favorable to the emergence of the tamarind seedlings. The substrates containing cattle manure provided the best conditions for emergence in the environment covered with bacuri straw. The greenhouses and the screenhouse with the aluminized screen and the substrates containing manure provided the largest number of leaves, larger plants, and larger diameters. The mixture of cassava stems and cattle manure, as well as the mixture of three or four tested materials, are conducive to the development and accumulation of biomass in tamarind seedlings. The mixture of humus with vermiculite or cassava stems is not indicated for the biomass accumulation in tamarind seedlings. Greenhouses and screens are indicated for the formation of high-quality seedlings.
\end{abstract}

Keywords: Tamarindus indica, cattle manure, cassava stems, humus, protected cultivation.

\section{Mudas de tamarindeiro em ambientes protegidos e substratos}

\section{RESUMO}

Este estudo objetivou avaliar a formação de mudas de tamarindeiro em diferentes ambientes protegidos e substratos. Foram utilizados cinco ambientes protegidos e substratos a partir de combinações de diferentes proporções de húmus, esterco bovino, vermiculita e ramas de mandioca. Os ambientes telados e os ambientes com filme de polietileno foram propícios à emergência do tamarindeiro e todos os substratos apresentaram condições adequadas à emergência das plântulas nesses ambientes. $\mathrm{O}$ ambiente coberto com palha nativa não foi favorável à emergência do tamarindeiro e os substratos contendo esterco bovino propiciaram as melhores condições à emergência nesse ambiente. As estufas e o telado aluminizado, assim como os substratos contendo esterco, propiciaram a maior quantidade de número de folhas, plantas maiores e com maiores diâmetros. A mistura de ramas e esterco, assim como a mistura de três ou quatro materiais testados, são propícios ao desenvolvimento e ao acúmulo de biomassa em mudas de tamarindeiro. A mistura de húmus com vermiculita ou ramas não é indicada para o acúmulo de biomassa em mudas de tamarindeiro. As estufas e os telados são indicados para a formação de mudas de elevada qualidade.

Palavras-chave: Tamarindus indica, esterco bovino, ramas de mandioca, húmus, cultivo protegido. 


\section{Introduction}

Originating in tropical Africa, the tamarind tree (Tamarindus indica L.) has stood out among the many exotic fruit trees grown in Brazil, as it is a crop easily adaptable to edaphoclimatic conditions, being quite resistant to drought but susceptible to the action of frosts (Pereira et al., 2010). Fruits are used in the manufacture of food in the form of popsicles, ice cream, sweets, jellies, concentrated juices, and condiments (El-Siddig et al., 2006).

The production of healthy and well-developed seedlings is an extremely important factor for any crop, especially perennials such as tamarind trees. Thus, the initial phase of the crop is decisive for the success of the orchard: any mistake made in the seedling production process may cause damage to the period of exploitation of the crop (Pereira et al., 2008; Góes et al., 2011). In this sense, research regarding the substrates and the protected environments of the crop are fundamental for the germination process and establishment of the seedling, as factors such as structure, aeration, water retention capacity, and degree of contamination by pathogens may vary according to the material used, favoring or harming seed germination (Alves et al., 2011).

The choice of substrate helps to provide adequate conditions for seedling emergence, and substrates with better textures can provide good conditions for germination and an appropriate supply of nutrients for the development of the root system and the shoot of the seedlings (Negreiros et al., 2004; Negreiros et al., 2005). With this, researchers seek to identify those that promote better conditions for the development of seedlings. Besides the substrates, the cultivation environment also influences the plant's initial development, adding vigor to the seedlings and, consequently, better adaptation and survival in the field (Cavalcante et al., 2002; Costa et al., 2009).

The use of protected environments implies several micrometeorological changes that alter environmentsubstrate-plant relationships. Local environmental aspects such as temperature, relative humidity, solar radiation, winds, and rain are extremely important in the seedling formation process, as well as the different types of cover material used in the environments, which can influence plant protection, promoting differentiation in heating, rainwater intake, brightness, among other factors, causing the characteristics and structure of the substrates to be modified (Araujo et al., 2006; Costa et al., 2011).

Due to the potential use of tamarind trees in Brazil and the great importance of plants' initial development to establish this species, the present study aimed to evaluate the initial growth and formation of tamarind seedlings in different conditions of protected environments and substrates.

\section{Material and Methods}

The research with the tamarind tree (Tamarindus indica L.) was conducted at the State University of Mato Grosso do Sul, University Unit of Aquidauana $\left(20^{\circ} 27^{\prime} 00^{\prime \prime}\right.$ S, 55 40'12" W, and altitude of $200 \mathrm{~m}$ ), between December 2011 and February 2012. According to the Köppen classification, the region's climate is Aw, defined as a humid tropical climate with an average annual temperature of $29^{\circ} \mathrm{C}$.

The development of tamarind seedlings was evaluated in different environments of protected cultivation and substrates. Five protected environments were used: A1 - agricultural greenhouse, arc model, with a galvanized steel structure $8.0 \mathrm{~m}$ wide by $18.0 \mathrm{~m}$ long, $4.0 \mathrm{~m}$ height under the gutter, covered with a polyethylene film of $150 \mu \mathrm{m}$ light diffuser, with a zenithal opening along the ridge, side and front closures with monofilament mesh, and mesh of 50\% shading; A2 - identical to A1 in dimensions and materials, but with a thermo-reflective screen complement of 50\% shading under the polyethylene film; A3 - screenhouse, with galvanized steel structure $8.0 \mathrm{~m}$ wide by $18.0 \mathrm{~m}$ long and $3.5 \mathrm{~m}$ high, closing at $45^{\circ}$ of inclination, with monofilament mesh throughout its extent, and mesh of $50 \%$ shading (Sombrite ${ }^{\circledR}$ ); A4 - screenhouse identical to A3 in dimensions, but with thermo-reflective screen closure with a mesh of $50 \%$ shading (Aluminet ${ }^{\circledR}$ ); and A5 - nursery covered with straw from the region's native palm, popularly known as bacuri, built of wood, with dimensions of $3.0 \mathrm{~m}$ long by $1.2 \mathrm{~m}$ wide by $1.7 \mathrm{~m}$ high.

The substrates were composed of combinations of different proportions of humus $(\mathrm{H})$, cattle manure $(\mathrm{M})$, vermiculite $(\mathrm{V})$ and cassava stems $(\mathrm{C})$, as follows: $\mathrm{S} 1=25 \%$ $\mathrm{H}+75 \% \mathrm{~V} ; \mathrm{S} 2=50 \% \mathrm{H}+50 \% \mathrm{~V} ; \mathrm{S} 3=75 \% \mathrm{H}+25 \% \mathrm{~V}$; $\mathrm{S} 4=25 \% \mathrm{H}+75 \% \mathrm{C} ; \mathrm{S} 5=50 \% \mathrm{H}+50 \% \mathrm{C} ; \mathrm{S} 6=75 \% \mathrm{H}$ $+25 \% \mathrm{C} ; \mathrm{S} 7=25 \% \mathrm{M}+75 \% \mathrm{~V} ; \mathrm{S} 8=50 \% \mathrm{M}+50 \% \mathrm{~V} ; \mathrm{S} 9$ $=75 \% \mathrm{M}+25 \% \mathrm{~V} ; \mathrm{S} 10=25 \% \mathrm{M}+75 \% \mathrm{C} ; \mathrm{S} 11=50 \% \mathrm{M}$ $+50 \% \mathrm{C} ; \mathrm{S} 12=75 \% \mathrm{M}+25 \% \mathrm{C} ; \mathrm{S} 13=33.3 \% \mathrm{H}+33.3 \%$ $\mathrm{M}+33.3 \% \mathrm{~V} ; \mathrm{S} 14=33.3 \% \mathrm{H}+33.3 \% \mathrm{M}+33.3 \% \mathrm{C}$; and $\mathrm{S} 15=25 \% \mathrm{H}+25 \% \mathrm{M}+25 \% \mathrm{~V}+25 \% \mathrm{C}$.

Cattle manure and cassava stems were obtained in Aquidauana-MS and composted for 30 and 60 days, respectively. Before being composted, the cassava stems were crushed in a hammer mill with an $8 \mathrm{~mm}$ sieve. The superfine humus and vermiculite were purchased commercially.

For organic materials, chemical analyzes of $\mathrm{N}, \mathrm{P}, \mathrm{K}$, $\mathrm{Ca}, \mathrm{Mg}, \mathrm{S}, \mathrm{C}, \mathrm{OM}$ (g kg-1), Cu, Zn, Fe, Mn, B (mg kg1), $\mathrm{pH}$, humidity (\%) and Carbon-to-nitrogen ratio $(\mathrm{C} / \mathrm{N})$, as follows: cattle manure $(10.6 ; 3.7 ; 1.0 ; 9.8 ; 1.7 ; 1.8$; $96.5 ; 166,0 ; 17.5 ; 75.0 ; 7800.0 ; 310.0 ; 11.5 ; 6.5 ; 2.9$; 9.1), earthworm humus $(14.8 ; 4.5 ; 1,0 ; 26.7 ; 12.5 ; 3.5$; $163.0 ; 281.0 ; 30.0 ; 130.0 ; 14800.0 ; 370.0 ; 14.4 ; 6.9$; $13.5 ; 11.0)$, cassava stems $(19.5 ; 2.9 ; 7.0 ; 18.8 ; 6.2 ; 2.4$; $376.0 ; 647.0 ; 87.5 ; 3440.0 ; 520,0 ; 20.7 ; 7.2 ; 11.2 ; 19.3)$. 
The wet and dry densities of the substrates were, respectively, (kg m-3): S1 (791.1; 279.8); S2 (958.7; 479.7); S3 (1104.5; 500.6); S4 (931.5; 273.7); S5 (1146.2; 502.11); S6 (1229.1; 648.2); S7 (648.1; 209.5); S8 (741.2; 270.4); S9 (838.1; 399.5); S10 (652.2, 216.6); S11 (700.3; 244.1), S12 (816.0; 376.3); S13 (956.7; 443.0); S14 (766.9; 289.9) and S15 (988.1; 457.0).

The collection of tamarind seeds was carried out in the region of Aquidauana-MS in December 2011. After being removed from the fruits, the seeds were washed, dried under the shade for $48 \mathrm{~h}$, and, subsequently, selected as to size and shape; those with defects were discarded. Subsequently, the seeds were immersed in water for 24 hours to overcome dormancy. For the formation of the seedlings, polyethylene bags (size of $0.15 \times 0.22 \mathrm{~m}$ and volume of $1.6 \mathrm{l}$ ) were used.

On December 27, 2011, two tamarind seeds were placed per container at approximately $0.02 \mathrm{~m}$ depth. Irrigation was manual, with the help of watering cans, and occurred twice a day. Plant thinning was carried out at 21 days after sowing (DAS), when the emergence stabilized.

To analyze the difference in treatments, the emergency speed index (ESI) proposed by Maguire (1962) was evaluated, in which data were collected daily until the emergence stabilized, that is when there was a repetition of the number of emerged plants for three consecutive days of at least one of the treatments; at 60 DAS, the number of leaves, the plant height $(\mathrm{cm})$, the stem diameter $(\mathrm{mm})$, the shoot dry matter $(\mathrm{g})$, and the root dry matter $(\mathrm{g})$ were evaluated.

The plant height was obtained using a measuring tape, and the diameter was measured with a caliper. To obtain the dry matter of shoot (SDM) and root system (RDM), the parts were placed individually in paper bags and subjected to drying in an air-forced circulation oven, at $65 \mathrm{oC}$, until reach constant weight. The total dry matter (TDM) was estimated by the sum of SDM and RDM. Dickson quality index (DQI) was calculated by Equation 1 (Dickson et al., 1960).

$$
\mathrm{DQI}=\frac{\mathrm{TDM}(\mathrm{g})}{\frac{\mathrm{PH}(\mathrm{cm})}{\mathrm{SD}(\mathrm{mm})}+\frac{\mathrm{SDM}(\mathrm{g})}{\operatorname{RDM}(\mathrm{g})}} \quad \text { Equation } 1
$$

The dry and wet bulb temperatures were automatically measured at 9:00 am, 12:00 pm, and 3:00 $\mathrm{pm}$, and later, by psychrometry, the relative humidity was determined. The dry bulb temperature $\left({ }^{\circ} \mathrm{C}\right)$, the wet bulb temperature $\left({ }^{\circ} \mathrm{C}\right)$ and the relative air humidity $(\%)$ at 9:00 am, 12:00 pm, and 3:00 pm, were as follows: external environment $\left(28.3 ; 24.7 ; 33.0 ; 26.4 ; 33.6 ; 26.6^{\circ} \mathrm{C} ; 74.9\right.$; $60.0 ; 58.4 \%)$; A1 $\left(29.5 ; 25.6 ; 32.9 ; 26.6 ; 33.5 ; 26.4^{\circ} \mathrm{C}\right.$; $73.7 ; 61.6 ; 57.8 \%) ;$ A $2(28.4 ; 24.6 ; 32.5 ; 25.9 ; 33.6 ; 25.9$ $\left.{ }^{\circ} \mathrm{C} ; 73.7 ; 59.7 ; 54.8 \%\right)$; A3 (29.2; 24.8; 33.5; 26.3; 35.1; $\left.26.5^{\circ} \mathrm{C} ; 70.3 ; 57.3 ; 51.5 \%\right)$; A4 (28.1; 24.9; 32.7; 26.6; $\left.33.3 ; 26.6^{\circ} \mathrm{C} ; 77.5 ; 62.5 ; 59.7 \%\right)$; and A5 (27.9; 25.1; $\left.31.6 ; 26.1 ; 32.3 ; 26.1^{\circ} \mathrm{C} ; 80.0 ; 65.2 ; 61.7 \%\right)$.
As there are no replications of the cultivation environments, each environment was considered an experimental unit. For each environment, a completely randomized design was adopted, with six replications of five seedlings each. Subsequently, the treatment averages were subjected to analysis of individual variances of the substrates, followed by evaluating the average squares of the residues (Banzatto and Kronka, 2013). The joint analysis was carried out to verify the effect of the cultivation environment. The Sisvar 5.3 statistical program (Ferreira, 2010) was used, the means were grouped by the Scott-Knott test at $5 \%$ probability.

\section{Results and Discussion}

In the evaluated parameters, it was observed that the relations between the average squares of the residue were less than 7: 1 (Table 1), allowing, therefore, the accomplishment of the joint analysis of the experiments and the comparison of the cultivation environments (Banzato and Kronka, 2013). The emergence percentage ranged between 72.11 and $87.89 \%$, being higher than that found by Silva et al. (2011), who evaluated the germination time and the initial development of seedlings of Tamarindus indica L. and found a variation from 52\% to $70 \%$ of emerged seedlings. This fact can be explained by the micrometeorological conditions of the Aquidauana region (warm region) and by the time of the experiment development (December to February - rainy season), which provided adequate conditions for the rapid germination and emergence of the tamarind seedlings.

In general, the A1 environment provided high temperatures at the three evaluated times. The result indicates that the agricultural greenhouse coated on the top with a polyethylene film could increase its temperature due to the greenhouse effect. The rise in temperature observed in A1 favored the emergence speed index of tamarind seedlings (Table 2), as this species is adapted to high temperatures, corroborating Santos et al. (2011), who, when evaluating protected environments and substrates in the formation of seedlings of Hymenaea stigonocarpa Mart. found that the agricultural greenhouse provided the seedlings with a higher ESI. According to the same authors, this environment stored more thermal energy at night, which may have favored greater metabolism and, thus, accelerated the seedling emergence, even though there was no great difference concerning A3 (Table 2). The percentage of emergence ranged between 72.11 and $87.89 \%$.

$\mathrm{A} 2, \mathrm{~A} 3$, and A4 environments did not present differences regarding the ESI (Table 2). The side protection and the roof with screen minimized the action of the wind, keeping the substrates in conditions of humidity favorable to the emergence (higher emergence 
speed index). In A5, the lack of lateral protection may have allowed natural ventilation to interfere with the substrates' conditions (humus and vermiculite; humus and cassava stems; and manure and vermiculite), providing less favorable conditions for emergence, especially in mixtures of manure or humus with vermiculite. The substrates $\mathrm{S} 1$ and $\mathrm{S} 7$ showed low densities, with 279.83 and $209.47 \mathrm{~kg} \mathrm{~m}^{-3}$, respectively, due to the high concentration of vermiculite $(75 \%)$. According to Freitas et al. (1980), vermiculite acts on the substrate water, retaining it and making it more available to plants; however, Gasparin et al. (2012) observed in the laboratory that this material loses water more easily when compared to sand, which may explain the fact that these substrates with a greater amount of vermiculite have presented unfavorable results of ESI.

Table 1. Analysis of variance with the calculated F, coefficient of variation (CV) and the relationship between the largest and the smallest mean square of the residue for the emergence speed index (ESI), number of leaves (NL), plant height (PH), stem diameter (SD), shoot dry matter (SDM), root dry matter (RDM), total dry matter (TDM) and Dickson quality index (DQI) of the tamarind seedlings. Aquidauana-MS, 2011-2012.

\begin{tabular}{lcccccccc}
\hline & ESI & NL & PH & SD & SDM & RDM & TDM & DQI \\
\hline Environment & $33.5^{* *}$ & $137.6^{* *}$ & $196.4^{* *}$ & $48.1^{* *}$ & $106.7^{* *}$ & $59.3^{* *}$ & $108.5^{* *}$ & $72.2^{* *}$ \\
Substrate & $5.3^{* *}$ & $7.9^{* *}$ & $40.1^{* *}$ & $11.6^{* *}$ & $40.2^{* *}$ & $25.1^{* *}$ & $40.0^{* *}$ & $22.2^{* *}$ \\
Interaction & $1.4^{*}$ & $2.1^{* *}$ & $3.2^{* *}$ & $1.4^{*}$ & $2.2^{* *}$ & $1.9^{* *}$ & $2.1^{* *}$ & $1.7^{* *}$ \\
CV (\%) & 25.5 & 14.3 & 7.7 & 7.4 & 16.9 & 17.5 & 16.0 & 17.0 \\
RMSR & 1.5 & 2.1 & 1.1 & 2.7 & 3.2 & 2.2 & 3.1 & 2.6 \\
\hline
\end{tabular}

NS = Not significant $; *=$ Significant at $1 \% ; *=$ Significant at 5\%; CV = Coefficient of Variation; RSMR = Relationship between the largest and the smallest mean square of the residue of the analysis of the substrates within the cultivation environments.

Table 2. Interaction between environments and substrates (A x S) for the emergence speed index (ESI) and stem diameter (SD) of the tamarind seedlings. Aquidauana-MS, 2011-2012.

\begin{tabular}{|c|c|c|c|c|c|}
\hline \multirow[t]{2}{*}{ ** } & \multicolumn{5}{|c|}{ Emergence speed index } \\
\hline & A1 & $\mathrm{A} 2$ & $\mathrm{~A} 3$ & A4 & A5 \\
\hline $25 \% \mathrm{H}+75 \% \mathrm{~V}$ & $4.02 \mathrm{aA}^{*}$ & $3.06 \mathrm{bA}$ & $3.04 \mathrm{bA}$ & $2.63 \mathrm{bA}$ & $2.12 \mathrm{bB}$ \\
\hline $50 \% \mathrm{H}+50 \% \mathrm{~V}$ & $3.66 \mathrm{aA}$ & $2.67 \mathrm{aA}$ & $3.06 \mathrm{aA}$ & $2.64 \mathrm{aA}$ & $2.50 \mathrm{aB}$ \\
\hline $75 \% \mathrm{H}+25 \% \mathrm{~V}$ & $3.10 \mathrm{aB}$ & $2.92 \mathrm{aA}$ & $2.27 \mathrm{aA}$ & $2.76 \mathrm{aA}$ & $2.05 \mathrm{aB}$ \\
\hline $25 \% \mathrm{H}+75 \% \mathrm{~V}$ & $4.26 \mathrm{aA}$ & $2.84 \mathrm{bA}$ & $2.80 \mathrm{bA}$ & $2.18 \mathrm{bA}$ & $2.26 \mathrm{bB}$ \\
\hline $50 \% \mathrm{H}+50 \% \mathrm{C}$ & $3.95 \mathrm{aA}$ & $2.58 \mathrm{bA}$ & $3.33 \mathrm{aA}$ & $3.29 \mathrm{aA}$ & $2.27 \mathrm{bB}$ \\
\hline $75 \% \mathrm{H}+25 \% \mathrm{C}$ & $3.74 \mathrm{aA}$ & $2.87 \mathrm{bA}$ & $2.59 \mathrm{bA}$ & $2.61 \mathrm{bA}$ & $1.80 \mathrm{bB}$ \\
\hline $25 \% \mathrm{M}+75 \% \mathrm{~V}$ & $3.40 \mathrm{aA}$ & $3.21 \mathrm{aA}$ & $3.08 \mathrm{aA}$ & $2.34 \mathrm{bA}$ & $2.01 \mathrm{bB}$ \\
\hline $50 \% \mathrm{M}+50 \% \mathrm{~V}$ & $3.84 \mathrm{aA}$ & $3.45 \mathrm{aA}$ & $3.45 \mathrm{aA}$ & $3.28 \mathrm{aA}$ & $2.10 \mathrm{bB}$ \\
\hline $75 \% \mathrm{M}+25 \% \mathrm{~V}$ & $3.71 \mathrm{aA}$ & $3.60 \mathrm{aA}$ & $3.49 \mathrm{aA}$ & $2.87 \mathrm{aA}$ & $2.94 \mathrm{aA}$ \\
\hline $25 \% \mathrm{M}+75 \% \mathrm{C}$ & $2.21 \mathrm{bB}$ & $3.06 \mathrm{aA}$ & $3.39 \mathrm{aA}$ & $3.16 \mathrm{aA}$ & $1.82 \mathrm{bB}$ \\
\hline $50 \% M+50 \% C$ & $3.65 \mathrm{aA}$ & $3.29 \mathrm{aA}$ & $3.19 \mathrm{aA}$ & $3.30 \mathrm{aA}$ & $3.27 \mathrm{aA}$ \\
\hline $75 \% \mathrm{M}+25 \% \mathrm{C}$ & $5.02 \mathrm{aA}$ & $4.01 \mathrm{bA}$ & $3.58 \mathrm{cA}$ & $3.09 \mathrm{cA}$ & $2.79 \mathrm{cA}$ \\
\hline $33.3 \% \mathrm{H}+33.3 \% \mathrm{M}+33.3 \% \mathrm{~V}$ & $3.74 \mathrm{aA}$ & $3.85 \mathrm{aA}$ & $3.67 \mathrm{aA}$ & $3.06 \mathrm{bA}$ & $2.80 \mathrm{bA}$ \\
\hline $33.3 \% \mathrm{H}+33.3 \% \mathrm{M}+33.3 \% \mathrm{C}$ & $4.16 \mathrm{aA}$ & $3.25 \mathrm{aA}$ & $2.80 \mathrm{aA}$ & $3.41 \mathrm{aA}$ & $3.25 \mathrm{aA}$ \\
\hline \multirow[t]{2}{*}{$25 \% \mathrm{H}+25 \% \mathrm{M}+25 \% \mathrm{~V}+25 \% \mathrm{C}$} & $4.30 \mathrm{aA}$ & $3.57 \mathrm{aA}$ & $3.71 \mathrm{aA}$ & $3.14 \mathrm{bA}$ & $2.86 \mathrm{bA}$ \\
\hline & \multicolumn{5}{|c|}{ Stem diameter $(\mathrm{mm})$} \\
\hline $25 \% \mathrm{H}+75 \% \mathrm{~V}$ & $3.40 \mathrm{aB}$ & $3.22 \mathrm{aB}$ & $3.31 \mathrm{aA}$ & $3.36 \mathrm{aB}$ & $2.88 \mathrm{bB}$ \\
\hline $50 \% \mathrm{H}+50 \% \mathrm{~V}$ & $3.62 \mathrm{aA}$ & $3.38 \mathrm{aB}$ & $3.31 \mathrm{aA}$ & $3.53 \mathrm{aB}$ & $2.91 \mathrm{bB}$ \\
\hline $75 \% \mathrm{H}+25 \% \mathrm{~V}$ & $3.31 \mathrm{aB}$ & $3.24 \mathrm{aB}$ & $3.28 \mathrm{aA}$ & $3.52 \mathrm{aB}$ & $2.92 \mathrm{bB}$ \\
\hline $25 \% \mathrm{H}+75 \% \mathrm{~V}$ & $3.18 \mathrm{aB}$ & $3.11 \mathrm{aB}$ & $2.94 \mathrm{aB}$ & $3.08 \mathrm{aC}$ & $3.03 \mathrm{aB}$ \\
\hline $50 \% \mathrm{H}+50 \% \mathrm{M}$ & $3.22 \mathrm{aB}$ & $3.27 \mathrm{aB}$ & $3.07 \mathrm{aB}$ & $3.39 \mathrm{aB}$ & $3.06 \mathrm{aB}$ \\
\hline $75 \% \mathrm{H}+25 \% \mathrm{M}$ & $3.44 \mathrm{aB}$ & $3.29 \mathrm{aB}$ & $3.11 \mathrm{bB}$ & $3.31 \mathrm{aB}$ & $2.99 \mathrm{bB}$ \\
\hline $25 \% \mathrm{E}+75 \% \mathrm{~V}$ & $3.39 \mathrm{bB}$ & $3.39 \mathrm{bB}$ & $3.34 \mathrm{bA}$ & $3.68 \mathrm{aA}$ & $2.79 \mathrm{cB}$ \\
\hline $50 \% \mathrm{E}+50 \% \mathrm{~V}$ & $3.65 \mathrm{aA}$ & $3.55 \mathrm{aA}$ & $3.48 \mathrm{aA}$ & $3.61 \mathrm{aA}$ & $3.12 \mathrm{bA}$ \\
\hline $75 \% \mathrm{E}+25 \% \mathrm{~V}$ & $3.83 \mathrm{aA}$ & $3.39 \mathrm{bB}$ & $3.37 \mathrm{bA}$ & $3.81 \mathrm{aA}$ & $3.40 \mathrm{bA}$ \\
\hline $25 \% \mathrm{E}+75 \% \mathrm{M}$ & $3.76 \mathrm{aA}$ & $3.34 \mathrm{bB}$ & $3.39 \mathrm{bA}$ & $3.68 \mathrm{aA}$ & $2.86 \mathrm{cB}$ \\
\hline $50 \% \mathrm{E}+50 \% \mathrm{M}$ & $3.66 \mathrm{aA}$ & $3.57 \mathrm{aA}$ & $3.55 \mathrm{aA}$ & $3.89 \mathrm{aA}$ & $3.13 \mathrm{bA}$ \\
\hline $75 \% \mathrm{E}+25 \% \mathrm{M}$ & $3.75 \mathrm{aA}$ & $3.61 \mathrm{aA}$ & $3.52 \mathrm{aA}$ & $3.64 \mathrm{aA}$ & $3.51 \mathrm{aA}$ \\
\hline $33.3 \% \mathrm{H}+33.3 \% \mathrm{E}+33.3 \% \mathrm{~V}$ & $3.43 \mathrm{aB}$ & $3.62 \mathrm{aA}$ & $3.52 \mathrm{aA}$ & $3.67 \mathrm{aA}$ & $3.18 \mathrm{bA}$ \\
\hline $33.3 \% \mathrm{H}+33.3 \% \mathrm{E}+33.3 \% \mathrm{M}$ & $3.57 \mathrm{aA}$ & $3.52 \mathrm{aA}$ & $3.29 \mathrm{aA}$ & $3.48 \mathrm{aB}$ & $3.26 \mathrm{aA}$ \\
\hline $25 \% \mathrm{H}+25 \% \mathrm{E}+25 \% \mathrm{~V}+25 \% \mathrm{M}$ & $3.64 \mathrm{a} A$ & $3.51 \mathrm{aA}$ & $3.38 \mathrm{aA}$ & $3.47 \mathrm{aB}$ & $3.29 \mathrm{aA}$ \\
\hline
\end{tabular}

* Equal uppercase letters in the columns and lowercase letters in the lines belong to the same group by the Scott-Knott test at 5\% probability; $\mathrm{A} 1=$ agricultural greenhouse; $\mathrm{A} 2=$ agricultural greenhouse with thermo-reflective screen under the film; $\mathrm{A} 3=\mathrm{screenhouse}$ with monofilament screen; A4 = screenhouse with thermo-reflective screen; A5 = nursery with bacuri straw; $\mathrm{H}=$ earthworm humus; $\mathrm{V}=$ vermiculite; $\mathrm{E}=$ cattle manure; $\mathrm{M}=$ cassava stems. 
In $\mathrm{A} 1$, the substrates " $\mathrm{S} 3=75 \%$ humus $+25 \%$ vermiculite" and "S10 $=25 \%$ cattle manure $+75 \%$ cassava stems" interfered negatively in the emergence (Table 2). By the substrates' density, it is possible to observe that the S3 presented a high dry density (500.62 $\mathrm{kg} \mathrm{m}^{-3}$ ). The high proportion of earthworm humus may have increased the density of $\mathrm{S} 3$, causing a reduction in aeration capacity (Alves et al., 2011) and, consequently, resulting in unfavorable conditions to the ESI. In S10, on the other hand, the low ESI can be explained by the high proportion of cassava stems $(75 \%)$, which may have caused a reduction in the moisture retention capacity. About A1, the plastic cover without the mesh may have interfered with the conditions of the substrates with a high percentage of humus or cassava stems and provided less favorable humidity conditions than the other substrates, causing the plants to emerge more slowly.

In comparing substrates for each environment, it is observed that A1, except for substrate S10, presented favorable conditions for emergence for all other substrates (Table 2), corroborating with Costa et al. (2012a). They observed higher emergence values in an environment with polyethylene film compared to the environments with the screen. The polyethylene film stores thermal energy, favoring the emergence of tamarind seedlings since this species is originating from a warm climate.

In the interaction between substrates and environments, it was observed that for ESI, the S2, S3, S9, S11, and S14 substrates did not differ in all the cultivation environments used. For the S1, S4, S6, and S12 substrates, the seedlings presented a higher ESI in the greenhouse without the thermo-reflective screen (A1); the S7, S13, and S15 substrates did not differ in A1, A2, and A3 environments (Table 2). Still, for the ESI, the A1, A3, and A4 environments did not show differences when using the substrate with $50 \%$ humus $+50 \%$ cassava stems (S5); for the substrate with $25 \%$ cattle manure + $75 \%$ cassava stems ( $\mathrm{S} 10)$, the plants did not differ in A2, $\mathrm{A} 3$, and A4 environments. In the proportions of $50 \%$ cattle manure $+50 \%$ vermiculite (S8), the seedlings had lower values of emergence speed index in the nursery covered with bacuri straw (A5) (Table 2).

Protected substrates and environments that promote rapid and uniform seed germination are desirable for seedling formation because the longer the seedling takes to emerge, the longer it will remain in the early stages of development, and the more vulnerable it will be to adverse conditions in the environment (Martins et al., 1999).

The stem diameter, in general, is the most observed characteristic to indicate the initial increments of development and the survival capacity of the seedling in the field (Daniel et al., 1997). It is observed that in the A1 environment, the S2, S8, S9, S10, S11, S12, S14, and S15 substrates were the ones that provided the greatest SD results. For the A2 environment, besides the S8 substrate, substrates ranging from S11 to S15 also provided similar results. For the screenhouse monofilament screen (A3), most substrates showed high SD values; only S4, S5, and S6 substrates had lower values than the others. In the A4 environment, it is possible to observe that the highest SD values were obtained in the substrates between S7 and S13, whereas for the A5 environment, the highest SD was found in the S8, S9, and from S11 to S15 substrates (Table 2).

In general, it is observed in all cultivation environments that there was a tendency to have higher $\mathrm{SD}$ in substrates ranging from S8 to S15 (Table 2). In substrates from 8 to 12 , it is noted that there is greater incorporation of cattle manure $(50 \%$ or $75 \%)$, except for $\mathrm{S} 10$, which has $25 \%$ of this material; with this, it was found that the use of cattle manure provided better conditions for the development of tamarind seedlings than the use of earthworm humus associated with another material (vermiculite or cassava stems). These results are similar to those of Pereira et al. (2010), who, when evaluating the size of containers and types of substrates in the quality of tamarind seedlings, observed that the use of cattle manure provided the largest increments in the stem diameter for the plants of the smallest containers when compared to the substrate with Plantmax ${ }^{\circledR}$. According to the same authors, the adequate development of seedlings with substrates containing cattle manure may be related not only to the content of nutrients but also to their effect on the substrate in microbiological processes, in aeration, in structuring, in the ability to water retention, and temperature regulation of the medium, as highlighted by Alves et al. (2011) regarding a substrate considered adequate.

In the results presented in Table 2, it was found that the S4, S5, S12, S14, and S15 substrates did not have significant differences regarding the stem diameter (SD) in all evaluated environments. And the other substrates (S1, S2, S3, S6, S7, S8, S9, S10, S11, and S13) promoted the lowest $\mathrm{SD}$ values in the environment covered with straw (A5), highlighting that S6 was no different in A3 and A5. The S9 did not differ in A2, A3, and A5 environments.

About the number of leaves (NL), it was found that, when analyzing the interaction between environments and substrates, in A1, the substrates that contained different percentages of earthworm humus and vermiculite (S1, S2, and S3) and the substrates ranging from $\mathrm{S} 8$ to $\mathrm{S} 14$ were the ones with the highest NL values. For A2, the highest NL values were obtained when the S1, S2, S5, S6, S7, S8, S10, S13, and S15 substrates were used. When analyzing the A3 environment, it is observed that all substrates are indicated for the NL of tamarind seedlings, except for $\mathrm{S} 4$, which presented a lower result 
than the others. For A4, the substrates S1, S4, S5, and S6 provided the lowest NL values. In A5, it was found that only the substrates that contained $75 \%$ cattle manure + $25 \%$ vermiculite (S9) and $75 \%$ cattle manure $+25 \%$ cassava stems (S12) had the highest amount of leaves (Table 3).

As for the leaf emission of tamarind seedlings, it is possible to see that the substrates, in general, showed better results in the greenhouse without a screen (A1) and in the screenhouse with an aluminized screen (A4) (Table 3 ). In the greenhouse, this may have occurred due to the greater radiation of light that this environment promoted in the initial phase of the experiment, and on the screenhouse, because of aluminized material, there is a greater spread of the incident light due to the diffuse radiation inside the environment. The tamarind tree, being a plant originating from a high-temperature region, was better adapted in the agricultural greenhouse, as it stores a greater amount of thermal energy, similar to Costa et al. (2012a) who also found a greater number of leaves of tamarind in the agricultural greenhouse when compared to screenhouses. In the greenhouse without a screen, the plants had an average of 26.2 leaves, and in the nursery of bacuri straw, it was 15.8 (Table 3).

About each substrate for the cultivation environments, it was verified, for the plant height, that in most of the substrates, the seedlings presented lower values when cultivated in the nursery covered with straw (A5). Plants with $26.64 \mathrm{~cm}$ were found in the S3 in the straw nursery, while in other environments, plants with up to $49.40 \mathrm{~cm}$ were observed in the $\mathrm{S} 12$ of the screened greenhouse, thus showing that the straw nursery did not favor the growth of tamarind seedlings (Table 3). This was possibly due to the lack of lateral protection of this environment, which facilitates the entry of insects seen during the conduct of the experiment and free access to the seedlings by the wind, being a negative influence on the production of seedlings in this environment. In protected environments, side screens are a good alternative to plant protection as they protect the crop against biotic and abiotic factors (Schallenberger et al., 2008).

As for the environments, it is observed that there is a propensity that the substrates containing humus associated with another material (S1 to S6) have exhibited the lowest heights of the tamarind seedlings in all cultivation environments (Table 3). This result is contradictory to that found by Góes et al. (2011), who found that with the increase in the proportion of earthworm humus in the substrate, they obtained a polynomial response to the height of the seedling, having an estimated maximum height of $30.9 \mathrm{~cm}$ at $65 \mathrm{DAS}$; in the present study, it was found that the maximum plant height reached at 60 DAS was $49.4 \mathrm{~cm}$, in the substrate that contained $75 \%$ of cattle manure and $25 \%$ of cassava stems (S12).
Negreiros et al. (2004) observed in soursop seedlings (Annona muricata L.) that substrates that contained cattle manure stood out as the best for plant height, stem diameter, and the number of definitive leaves. In the present study, substrates with $50 \%$ and $75 \%$ percentages of cattle manure (organic compost) were favorable to the growth of tamarind seedlings, differently from what was observed by Costa et al. (2012a), who found that $20 \%$ of Organosuper $^{\circledR}$ (organic compound) in the substrate increased the aerial part height of seedlings grown in an agricultural greenhouse.

It is noted that in the greenhouse with a thermoreflective screen (A2) and screenhouses (A3 and A4), plants were higher in most substrates. This may have occurred since these environments present the screen as a compliment, in the case of the greenhouse (A2), or are made of this material, whether black (A3) or aluminized (A4). According to Bezerra Neto et al. (2005), shading screens are increasingly used in agriculture due to studies carried out in this area that demonstrate satisfactory results concerning the lower incidence of sunlight, consequently ensuring greater productivity. Aluminum metalized meshes modify the intensity of light, promoting greater diffusion of light, increasing the efficiency of energy capture by plants, and, consequently, the efficiency of photosynthesis, as well as improving internal production conditions (Sousa Neto et al., 2010).

It appears that all the tested substrates had the smallest tamarind seedlings when the straw nursery (A5) was used, a result similar to the other height measures (PH1 and PH2); however, it is observed that the S1 and S5 substrates did not show differences between A1 and A5 environments, and S9 between A3 and A5 environments (Table 3). For agricultural greenhouses, it is noted that in the greenhouse without mesh (A1), the S8 and $\mathrm{S} 9$ substrates were superior concerning the others for the variable SDM. In the greenhouse, with mesh (A2), the best substrates were $\mathrm{S} 8, \mathrm{~S} 11, \mathrm{~S} 12$, and $\mathrm{S} 13$. In the black screen (A3), besides the substrates mentioned for $\mathrm{A} 2$, the $\mathrm{S} 15$ substrate also provided the best results. It is observed on the screenhouse with the aluminized screen (A4) that the substrates ranging from S7 to S15 provided conditions for the largest accumulations of SDM in the tamarind seedlings. In A5, only S9 and S12 substrates had the highest accumulations (Table 4).

Analyzing the interaction between environments and substrates for SDM, it appears that there was a tendency for the worst results in substrates ranging from S1 to S6, with some variations, in all cultivation environments. From the results of these substrates, it is noted in their composition that all contain 25,50 , or $75 \%$ of humus associated with cassava stems or vermiculite, showing that these mixtures were not conducive to developing the shoot of the tamarind seedlings (Table 4). These results contradict those of Pereira et al. (2010), who found that 
substrates composed of earthworm humus provided a greater shoot dry matter of tamarind seedlings at 180 DAS. In the chemical analysis of organic substrates, it is observed that the earthworm humus had a high zinc content $\left(130 \mathrm{mg} \cdot \mathrm{kg}^{-1}\right)$. The excess of zinc contained in this substrate may have caused phytotoxicity to the tamarind seedlings, as, as in the present study, Santos et al. (2011) also found for seedlings Hymenaea stigonocarpa, in substrates with different doses of commercial organic compost, that the zinc contents exaggerated with the increase in the percentages of compost, thus causing a toxic effect to the Jatobá seedlings.

Evaluating the substrates' performance, it is noted that all the substrates used in the experiment had the lowest accumulations of the shoot dry matter in the nursery of straw (A5), confirming, again, that this environment was not conducive to the development of tamarind seedlings. (Table 4). About the environments, it is observed that in the two agricultural greenhouses (A1 and A2) and the monofilament screen (A3), the S1, S7, and S8 substrates were the ones that provided greater mass accumulations in the root system of the tamarind seedlings, noting that in $\mathrm{A} 1$, the $\mathrm{S} 12$ and $\mathrm{A} 2$, the $\mathrm{S} 12$ and $\mathrm{S} 13$ also caused this effect. In the screen with a thermo-reflective screen (A4) and the straw nursery (A5), the substrates ranging from S8 to S15 stood out for presenting the highest RDM values, whereas, in A4, S1 and S7 did not differ from the substrates mentioned above (Table 4).

When observing the parameters of SDM and RDM (Table 4) in the environment covered with straw, it appears that there was a difference between them for substrates ranging from S8 to S15. In the SDM, these substrates provided low accumulations of shoot dry matter; however, it appears that the same substrates were the ones that presented the best accumulations of root dry matter of tamarind seedlings. These different responses of plants on the same substrates possibly occurred since the shoot was directly exposed to the winds, as this environment did not have lateral protection, and with this, they were more affected, and consequently, presented less shoot development; the roots, on the other hand, since they are inside the substrate, did not feel this action of the winds.

Table 3. Interaction between environments and substrates (A x S) for the number of leaves (NL) and plant height (PH) of the tamarind seedlings. Aquidauana-MS, 2011-2012.

\begin{tabular}{|c|c|c|c|c|c|}
\hline \multirow[t]{2}{*}{ ** } & \multicolumn{5}{|c|}{ Number of leaves } \\
\hline & A1 & $\mathrm{A} 2$ & A3 & A4 & A5 \\
\hline $25 \% \mathrm{H}+75 \% \mathrm{~V}$ & $28.1 \mathrm{aA}$ & $21.8 \mathrm{bA}$ & $21.0 \mathrm{bA}$ & $20.8 \mathrm{bB}$ & $16.6 \mathrm{cB}$ \\
\hline $50 \% \mathrm{H}+50 \% \mathrm{~V}$ & $27.7 \mathrm{aA}$ & $26.0 \mathrm{aA}$ & $22.5 \mathrm{bA}$ & $24.7 \mathrm{bA}$ & $15.1 \mathrm{cC}$ \\
\hline $75 \% \mathrm{H}+25 \% \mathrm{~V}$ & $25.8 \mathrm{aA}$ & $20.9 \mathrm{bB}$ & $22.3 \mathrm{bA}$ & $22.5 \mathrm{bA}$ & $13.5 \mathrm{cC}$ \\
\hline $25 \% \mathrm{H}+75 \% \mathrm{~V}$ & $22.1 \mathrm{aB}$ & $16.9 \mathrm{bB}$ & $15.5 \mathrm{bB}$ & $16.7 \mathrm{bB}$ & $14.5 \mathrm{bC}$ \\
\hline $50 \% \mathrm{H}+50 \% \mathrm{C}$ & $23.9 \mathrm{aB}$ & $22.4 \mathrm{aA}$ & $19.5 \mathrm{aA}$ & $20.8 \mathrm{aB}$ & $14.1 \mathrm{bC}$ \\
\hline $75 \% \mathrm{H}+25 \% \mathrm{C}$ & $24.0 \mathrm{aB}$ & $23.0 \mathrm{aA}$ & $20.0 \mathrm{bA}$ & $19.2 \mathrm{bB}$ & $12.8 \mathrm{cC}$ \\
\hline $25 \% \mathrm{M}+75 \% \mathrm{~V}$ & $23.0 \mathrm{aB}$ & $22.0 \mathrm{aA}$ & $22.3 \mathrm{aA}$ & $22.0 \mathrm{aA}$ & $13.5 \mathrm{bC}$ \\
\hline $50 \% \mathrm{M}+50 \% \mathrm{~V}$ & $28.2 \mathrm{aA}$ & $20.1 \mathrm{cA}$ & $23.5 \mathrm{bA}$ & $23.8 \mathrm{bA}$ & $16.4 \mathrm{~dB}$ \\
\hline $75 \% \mathrm{M}+25 \% \mathrm{~V}$ & $29.3 \mathrm{aA}$ & $17.5 \mathrm{cB}$ & $20.7 \mathrm{bA}$ & $22.9 \mathrm{bA}$ & $19.7 \mathrm{cA}$ \\
\hline $25 \% \mathrm{M}+75 \% \mathrm{C}$ & $26.5 \mathrm{aA}$ & $21.8 \mathrm{bA}$ & $20.2 \mathrm{cA}$ & $24.4 \mathrm{aA}$ & $15.4 \mathrm{dC}$ \\
\hline $50 \% \mathrm{M}+50 \% \mathrm{C}$ & $27.0 \mathrm{aA}$ & $20.5 \mathrm{bB}$ & $21.9 \mathrm{bA}$ & $22.9 \mathrm{bA}$ & $14.5 \mathrm{cC}$ \\
\hline $75 \% \mathrm{M}+25 \% \mathrm{C}$ & $28.0 \mathrm{aA}$ & $19.9 \mathrm{cB}$ & $23.8 \mathrm{bA}$ & $24.8 \mathrm{bA}$ & $20.5 \mathrm{cA}$ \\
\hline $33.3 \% \mathrm{H}+33.3 \% \mathrm{M}+33.3 \% \mathrm{~V}$ & $26.4 \mathrm{aA}$ & $23.0 \mathrm{bA}$ & $21.5 \mathrm{bA}$ & $24.9 \mathrm{aA}$ & $17.0 \mathrm{cB}$ \\
\hline $33.3 \% \mathrm{H}+33.3 \% \mathrm{M}+33.3 \% \mathrm{C}$ & $28.1 \mathrm{aA}$ & $20.0 \mathrm{bB}$ & $20.0 \mathrm{bA}$ & $25.0 \mathrm{aA}$ & $15.9 \mathrm{cC}$ \\
\hline \multirow[t]{2}{*}{$25 \% \mathrm{H}+25 \% \mathrm{M}+25 \% \mathrm{~V}+25 \% \mathrm{C}$} & $24.6 \mathrm{aB}$ & $22.8 \mathrm{aA}$ & $20.6 \mathrm{bA}$ & $26.2 \mathrm{aA}$ & $17.0 \mathrm{cB}$ \\
\hline & \multicolumn{5}{|c|}{ Plant height $(\mathrm{cm})$} \\
\hline $25 \% \mathrm{H}+75 \% \mathrm{~V}$ & $34.1 \mathrm{bD}$ & $38.0 \mathrm{aC}$ & $40.0 \mathrm{aB}$ & $38.6 \mathrm{aC}$ & $30.6 \mathrm{bB}$ \\
\hline $50 \% \mathrm{H}+50 \% \mathrm{~V}$ & $35.5 \mathrm{bC}$ & $42.8 \mathrm{aB}$ & $40.7 \mathrm{aB}$ & $43.6 \mathrm{aB}$ & $31.4 \mathrm{cB}$ \\
\hline $75 \% \mathrm{H}+25 \% \mathrm{~V}$ & $35.0 \mathrm{bC}$ & $38.3 \mathrm{bC}$ & $36.9 \mathrm{bC}$ & $42.0 \mathrm{aB}$ & $26.6 \mathrm{cC}$ \\
\hline $25 \% \mathrm{H}+75 \% \mathrm{~V}$ & $31.8 \mathrm{bD}$ & $34.3 \mathrm{bD}$ & $32.8 \mathrm{bD}$ & $36.7 \mathrm{aC}$ & $27.8 \mathrm{cC}$ \\
\hline $50 \% \mathrm{H}+50 \% \mathrm{C}$ & $32.6 \mathrm{cD}$ & $40.4 \mathrm{aC}$ & $36.5 \mathrm{bC}$ & $35.9 \mathrm{bC}$ & $30.8 \mathrm{cB}$ \\
\hline $75 \% \mathrm{H}+25 \% \mathrm{C}$ & $35.6 \mathrm{bC}$ & $42.8 \mathrm{aB}$ & $35.2 \mathrm{bD}$ & $36.4 \mathrm{bC}$ & $28.8 \mathrm{cC}$ \\
\hline $25 \% \mathrm{M}+75 \% \mathrm{~V}$ & $37.0 \mathrm{bC}$ & $43.0 \mathrm{aB}$ & $42.8 \mathrm{aA}$ & $42.5 \mathrm{aB}$ & $30.1 \mathrm{cB}$ \\
\hline $50 \% \mathrm{M}+50 \% \mathrm{~V}$ & $45.8 \mathrm{aA}$ & $45.7 \mathrm{aA}$ & $44.3 \mathrm{aA}$ & $42.9 \mathrm{aB}$ & $32.0 \mathrm{bB}$ \\
\hline $75 \% \mathrm{M}+25 \% \mathrm{~V}$ & $43.7 \mathrm{bA}$ & $42.1 \mathrm{bB}$ & $38.9 \mathrm{cC}$ & $46.8 \mathrm{aA}$ & $37.9 \mathrm{cA}$ \\
\hline $25 \% \mathrm{M}+75 \% \mathrm{C}$ & $42.9 \mathrm{aB}$ & $45.5 \mathrm{aA}$ & $44.4 \mathrm{aA}$ & $45.8 \mathrm{aA}$ & $31.9 \mathrm{bB}$ \\
\hline $50 \% \mathrm{M}+50 \% \mathrm{C}$ & $41.5 \mathrm{bB}$ & $48.0 \mathrm{aA}$ & $41.4 \mathrm{bB}$ & $49.2 \mathrm{aA}$ & $31.9 \mathrm{cB}$ \\
\hline $75 \% \mathrm{M}+25 \% \mathrm{C}$ & $44.5 \mathrm{bA}$ & $49.4 \mathrm{aA}$ & $44.3 \mathrm{bA}$ & $43.5 \mathrm{bB}$ & $36.4 \mathrm{cA}$ \\
\hline $33.3 \% \mathrm{H}+33.3 \% \mathrm{M}+33.3 \% \mathrm{~V}$ & $41.9 \mathrm{bB}$ & $48.0 \mathrm{aA}$ & $46.3 \mathrm{aA}$ & $45.6 \mathrm{aA}$ & $36.6 \mathrm{cA}$ \\
\hline $33.3 \% \mathrm{H}+33.3 \% \mathrm{M}+33.3 \% \mathrm{C}$ & $40.0 \mathrm{cB}$ & $46.7 \mathrm{aA}$ & $40.7 \mathrm{cB}$ & $43.2 \mathrm{bB}$ & $36.1 \mathrm{dA}$ \\
\hline $25 \% \mathrm{H}+25 \% \mathrm{M}+25 \% \mathrm{~V}+25 \% \mathrm{C}$ & $38.6 \mathrm{bC}$ & $43.9 \mathrm{aB}$ & $43.3 \mathrm{aA}$ & $44.7 \mathrm{aB}$ & $32.6 \mathrm{cB}$ \\
\hline
\end{tabular}

* Equal uppercase letters in the columns and lowercase letters in the lines belong to the same group by the Scott-Knott test at $5 \%$ probability; A1 = agricultural greenhouse; A2 = agricultural greenhouse with thermo-reflective screen under the film; A3 = screenhouse with monofilament screen; A4 = screenhouse with thermo-reflective screen; A5 = nursery with bacuri straw; $\mathrm{H}=$ earthworm humus; $\mathrm{V}=$ vermiculite; $\mathrm{E}=$ cattle manure; $\mathrm{M}$ = cassava stems. 
Table 4. Interaction between environments and substrates (A x S) for the shoot dry matter (SDM) and root system dry matter (RDM) of the tamarind seedlings. Aquidauana-MS, 2011-2012.

\begin{tabular}{|c|c|c|c|c|c|}
\hline & \multicolumn{5}{|c|}{ Shoot dry matter } \\
\hline & A1 & A2 & A3 & A4 & A5 \\
\hline $25 \% \mathrm{H}+75 \% \mathrm{~V}$ & $2.94 \mathrm{aC}$ & $2.63 \mathrm{aC}$ & $2.71 \mathrm{aB}$ & $2.74 \mathrm{aB}$ & $1.67 \mathrm{bC}$ \\
\hline $50 \% \mathrm{H}+50 \% \mathrm{~V}$ & $3.17 \mathrm{aC}$ & $3.08 \mathrm{aB}$ & $2.55 \mathrm{aC}$ & $2.83 \mathrm{aB}$ & $1.47 \mathrm{bC}$ \\
\hline $75 \% \mathrm{H}+25 \% \mathrm{~V}$ & $2.83 \mathrm{aC}$ & $2.22 \mathrm{bC}$ & $1.98 \mathrm{cD}$ & $2.78 \mathrm{aB}$ & $1.27 \mathrm{dC}$ \\
\hline $25 \% \mathrm{H}+75 \% \mathrm{~V}$ & $2.08 \mathrm{aD}$ & $1.80 \mathrm{bD}$ & $1.75 \mathrm{bD}$ & $2.26 \mathrm{aC}$ & $1.45 \mathrm{bC}$ \\
\hline $50 \% \mathrm{H}+50 \% \mathrm{C}$ & $2.15 \mathrm{aD}$ & $2.40 \mathrm{aC}$ & $1.87 \mathrm{bD}$ & $2.14 \mathrm{aC}$ & $1.52 \mathrm{bC}$ \\
\hline $75 \% \mathrm{H}+25 \% \mathrm{C}$ & $2.51 \mathrm{aD}$ & $2.79 \mathrm{aB}$ & $1.79 \mathrm{bD}$ & $2.05 \mathrm{bC}$ & $1.30 \mathrm{cC}$ \\
\hline $25 \% \mathrm{M}+75 \% \mathrm{~V}$ & $3.21 \mathrm{aC}$ & $2.97 \mathrm{aB}$ & $3.17 \mathrm{aB}$ & $3.64 \mathrm{aA}$ & $1.52 \mathrm{bC}$ \\
\hline $50 \% \mathrm{M}+50 \% \mathrm{~V}$ & $4.58 \mathrm{aA}$ & $3.31 \mathrm{bA}$ & $3.42 \mathrm{bA}$ & $3.62 \mathrm{bA}$ & $2.24 \mathrm{cB}$ \\
\hline $75 \% \mathrm{M}+25 \% \mathrm{~V}$ & $4.17 \mathrm{aA}$ & $3.09 \mathrm{bB}$ & $3.00 \mathrm{bB}$ & $3.68 \mathrm{aA}$ & $2.90 \mathrm{bA}$ \\
\hline $25 \% \mathrm{M}+75 \% \mathrm{C}$ & $3.63 \mathrm{aB}$ & $3.17 \mathrm{aB}$ & $3.12 \mathrm{aB}$ & $3.54 \mathrm{aA}$ & $2.27 \mathrm{bB}$ \\
\hline $50 \% \mathrm{M}+50 \% \mathrm{C}$ & $3.52 \mathrm{aB}$ & $3.58 \mathrm{aA}$ & $3.25 \mathrm{aA}$ & $3.76 \mathrm{aA}$ & $2.11 \mathrm{bB}$ \\
\hline $75 \% M+25 \% C$ & $3.72 \mathrm{aB}$ & $3.44 \mathrm{aA}$ & $3.57 \mathrm{aA}$ & $3.63 \mathrm{aA}$ & $2.92 \mathrm{bA}$ \\
\hline $33.3 \% \mathrm{H}+33.3 \% \mathrm{M}+33.3 \% \mathrm{~V}$ & $3.16 \mathrm{aC}$ & $3.61 \mathrm{aA}$ & $3.58 \mathrm{aA}$ & $3.63 \mathrm{aA}$ & $2.22 \mathrm{bB}$ \\
\hline $33.3 \% \mathrm{H}+33.3 \% \mathrm{M}+33.3 \% \mathrm{C}$ & $3.83 \mathrm{aB}$ & $3.22 \mathrm{aB}$ & $2.95 \mathrm{bB}$ & $3.36 \mathrm{aA}$ & $2.33 \mathrm{cB}$ \\
\hline $25 \% \mathrm{H}+25 \% \mathrm{M}+25 \% \mathrm{~V}+25 \% \mathrm{C}$ & $3.41 \mathrm{aB}$ & $2.98 \mathrm{aB}$ & $3.38 \mathrm{aA}$ & $3.48 \mathrm{aA}$ & $2.01 \mathrm{bB}$ \\
\hline ** & \multicolumn{5}{|c|}{ Root system dry matter } \\
\hline $25 \% \mathrm{H}+75 \% \mathrm{~V}$ & $0.86 \mathrm{aA}^{*}$ & $0.77 \mathrm{aA}$ & $0.80 \mathrm{aA}$ & $0.72 \mathrm{aA}$ & $0.49 \mathrm{bB}$ \\
\hline $50 \% \mathrm{H}+50 \% \mathrm{~V}$ & $0.74 \mathrm{aB}$ & $0.68 \mathrm{aB}$ & $0.60 \mathrm{aC}$ & $0.69 \mathrm{aB}$ & $0.32 \mathrm{bC}$ \\
\hline $75 \% \mathrm{H}+25 \% \mathrm{~V}$ & $0.57 \mathrm{aC}$ & $0.50 \mathrm{aC}$ & $0.50 \mathrm{aC}$ & $0.58 \mathrm{aB}$ & $0.32 \mathrm{bC}$ \\
\hline $25 \% \mathrm{H}+75 \% \mathrm{~V}$ & $0.64 \mathrm{aC}$ & $0.58 \mathrm{aC}$ & $0.54 \mathrm{aC}$ & $0.64 \mathrm{aB}$ & $0.45 \mathrm{bB}$ \\
\hline $50 \% \mathrm{H}+50 \% \mathrm{C}$ & $0.52 \mathrm{aC}$ & $0.56 \mathrm{aC}$ & $0.48 \mathrm{aC}$ & $0.59 \mathrm{aB}$ & $0.37 \mathrm{bC}$ \\
\hline $75 \% \mathrm{H}+25 \% \mathrm{C}$ & $0.55 \mathrm{aC}$ & $0.62 \mathrm{aC}$ & $0.52 \mathrm{aC}$ & $0.54 \mathrm{aB}$ & $0.32 \mathrm{bC}$ \\
\hline $25 \% \mathrm{M}+75 \% \mathrm{~V}$ & $0.97 \mathrm{aA}$ & $0.84 \mathrm{aA}$ & $0.85 \mathrm{aA}$ & $0.90 \mathrm{aA}$ & $0.40 \mathrm{bB}$ \\
\hline $50 \% \mathrm{M}+50 \% \mathrm{~V}$ & $0.94 \mathrm{aA}$ & $0.88 \mathrm{aA}$ & $0.83 \mathrm{aA}$ & $0.85 \mathrm{aA}$ & $0.61 \mathrm{bA}$ \\
\hline $75 \% \mathrm{M}+25 \% \mathrm{~V}$ & $0.78 \mathrm{aB}$ & $0.68 \mathrm{bB}$ & $0.60 \mathrm{bC}$ & $0.78 \mathrm{aA}$ & $0.66 \mathrm{bA}$ \\
\hline $25 \% \mathrm{M}+75 \% \mathrm{C}$ & $0.78 \mathrm{aB}$ & $0.68 \mathrm{bB}$ & $0.72 \mathrm{bB}$ & $0.85 \mathrm{aA}$ & $0.61 \mathrm{bA}$ \\
\hline $50 \% \mathrm{M}+50 \% \mathrm{C}$ & $0.73 \mathrm{aB}$ & $0.74 \mathrm{aB}$ & $0.62 \mathrm{bC}$ & $0.78 \mathrm{aA}$ & $0.54 \mathrm{bA}$ \\
\hline $75 \% M+25 \% C$ & $0.84 \mathrm{aA}$ & $0.78 \mathrm{aA}$ & $0.70 \mathrm{aB}$ & $0.79 \mathrm{aA}$ & $0.77 \mathrm{aA}$ \\
\hline $33.3 \% \mathrm{H}+33.3 \% \mathrm{M}+33.3 \% \mathrm{~V}$ & $0.69 \mathrm{aC}$ & $0.76 \mathrm{aA}$ & $0.70 \mathrm{aB}$ & $0.83 \mathrm{aA}$ & $0.65 \mathrm{aA}$ \\
\hline $33.3 \% \mathrm{H}+33.3 \% \mathrm{M}+33.3 \% \mathrm{C}$ & $0.76 \mathrm{aB}$ & $0.70 \mathrm{aB}$ & $0.63 \mathrm{bC}$ & $0.76 \mathrm{aA}$ & $0.61 \mathrm{bA}$ \\
\hline $25 \% \mathrm{H}+25 \% \mathrm{M}+25 \% \mathrm{~V}+25 \% \mathrm{C}$ & $0.76 \mathrm{aB}$ & $0.70 \mathrm{aB}$ & $0.73 \mathrm{aB}$ & $0.78 \mathrm{aA}$ & $0.56 \mathrm{bA}$ \\
\hline
\end{tabular}

* Equal uppercase letters in the columns and lowercase letters in the lines belong to the same group by the Scott-Knott test at $5 \%$ probability; A1 = agricultural greenhouse; A2 = agricultural greenhouse with thermo-reflective screen under the film; A3 = screenhouse with monofilament screen; A4 = screenhouse with thermo-reflective screen; A5 = nursery with bacuri straw; $\mathrm{H}=$ earthworm humus; $\mathrm{V}=$ vermiculite $\mathrm{E}=$ cattle manure $\mathrm{M}=$ cassava stems .

For the substrates, it appears that there was not much variation between them in the A1, A2, A3, and A4 environments; that is, all of these, in general, provided good results regarding the RDM of tamarind seedlings; however, it is observed that the tested substrates showed inferior results in the straw nursery (A5), except for S12 and S13, which did not differ in all environments used (Table 4).

In the environments, it is observed that from the substrate S7 to S15, the seedlings presented total biomasses that classify them as having higher quality than those produced in the substrates from S1 to S6 (Table 5). From this combination (S7), with 2, 3, or 4 raw materials, all formulations contained cattle manure, revealing that this material is fundamental in forming the tamarind seedling.

In the combination of substrates with higher percentages of cattle manure (50 and $75 \%$ ), higher total biomasses are observed in the plants grown on the screenhouses and in the greenhouse with polyethylene film due to the greater availability of nutrients for the development of the seedling. Costa et al. (2012b) observed that baruzeiro seedlings produced on substrates containing pure cattle manure $(100 \%)$ or mixture with vermiculite and cassava stems showed high quality. However, Dias et al. (2009) and Dias and Melo (2009) do not indicate the use of more than $30 \%$ of manure in the formation of coffee seedlings. However, in their work, the time and method of composting this material are not specified.

About the environments, it is observed that the greenhouses (A1 and A2) and the screenhouses (A3 and A4) provided adequate conditions for the development of seedlings (Table 5). Regarding the substrates, it appears that, as it could be visualized for the parameters of SDM and RDM, most of the substrates tested in the experiment did not present satisfactory results in the environment covered with straw (A5) because the plants cultivated in this environment exhibited the lowest accumulations of total dry matter (TDM) (Table 5). 
Table 5. Interaction between environments and substrates (A x S) for the total dry matter (TDM) and Dickson quality index (DQI) of the tamarind seedlings. Aquidauana-MS, 2011-2012.

\begin{tabular}{|c|c|c|c|c|c|}
\hline & \multicolumn{5}{|c|}{ Total dry matter } \\
\hline & A1 & $\mathrm{A} 2$ & A3 & A4 & A5 \\
\hline $25 \% \mathrm{H}+75 \% \mathrm{~V}$ & $3.80 \mathrm{aB}$ & $3.40 \mathrm{aB}$ & $3.51 \mathrm{aB}$ & $3.46 \mathrm{aB}$ & $2.16 \mathrm{bC}$ \\
\hline $50 \% \mathrm{H}+50 \% \mathrm{~V}$ & $3.91 \mathrm{aB}$ & $3.76 \mathrm{aB}$ & $3.14 \mathrm{aC}$ & $3.52 \mathrm{aB}$ & $1.7 \mathrm{bC}$ \\
\hline $75 \% \mathrm{H}+25 \% \mathrm{~V}$ & $3.40 \mathrm{aC}$ & $2.72 \mathrm{bC}$ & $2.48 \mathrm{bD}$ & $3.35 \mathrm{aB}$ & $1.58 \mathrm{cC}$ \\
\hline $25 \% \mathrm{H}+75 \% \mathrm{~V}$ & $2.72 \mathrm{aC}$ & $2.38 \mathrm{bC}$ & $2.29 \mathrm{bD}$ & $2.91 \mathrm{aC}$ & $1.95 \mathrm{bC}$ \\
\hline $50 \% \mathrm{H}+50 \% \mathrm{C}$ & $2.68 \mathrm{aC}$ & $2.96 \mathrm{aC}$ & $2.35 \mathrm{bD}$ & $2.73 \mathrm{aC}$ & $1.89 \mathrm{bC}$ \\
\hline $75 \% \mathrm{H}+25 \% \mathrm{C}$ & $3.06 \mathrm{aC}$ & $3.40 \mathrm{aB}$ & $2.31 \mathrm{bD}$ & $2.59 \mathrm{bC}$ & $1.62 \mathrm{cC}$ \\
\hline $25 \% \mathrm{M}+75 \% \mathrm{~V}$ & $4.17 \mathrm{aB}$ & $3.80 \mathrm{aB}$ & $4.02 \mathrm{aA}$ & $4.53 \mathrm{aA}$ & $1.92 \mathrm{bC}$ \\
\hline $50 \% \mathrm{M}+50 \% \mathrm{~V}$ & $5.52 \mathrm{aA}$ & $4.19 \mathrm{bA}$ & $4.25 \mathrm{bA}$ & $4.47 \mathrm{bA}$ & $2.85 \mathrm{cB}$ \\
\hline $75 \% \mathrm{M}+25 \% \mathrm{~V}$ & $4.97 \mathrm{aA}$ & $3.77 \mathrm{bB}$ & $3.60 \mathrm{bB}$ & $4.45 \mathrm{aA}$ & $3.56 \mathrm{bA}$ \\
\hline $25 \% \mathrm{M}+75 \% \mathrm{C}$ & $4.41 \mathrm{aB}$ & $3.84 \mathrm{aB}$ & $3.84 \mathrm{aB}$ & $4.38 \mathrm{aA}$ & $2.88 \mathrm{bB}$ \\
\hline $50 \% \mathrm{M}+50 \% \mathrm{C}$ & $4.25 \mathrm{aB}$ & $4.32 \mathrm{aA}$ & $3.86 \mathrm{aB}$ & $4.54 \mathrm{aA}$ & $2.64 \mathrm{bB}$ \\
\hline $75 \% M+25 \% C$ & $4.57 \mathrm{aB}$ & $4.21 \mathrm{aA}$ & $4.26 \mathrm{aA}$ & $4.41 \mathrm{aA}$ & $3.69 \mathrm{aA}$ \\
\hline $33.3 \% \mathrm{H}+33.3 \% \mathrm{M}+33.3 \% \mathrm{~V}$ & $3.85 \mathrm{aB}$ & $4.37 \mathrm{aA}$ & $4.28 \mathrm{aA}$ & $4.46 \mathrm{aA}$ & $2.87 \mathrm{bB}$ \\
\hline $33.3 \% \mathrm{H}+33.3 \% \mathrm{M}+33.3 \% \mathrm{C}$ & $4.59 \mathrm{aB}$ & $3.92 \mathrm{aB}$ & $3.57 \mathrm{bB}$ & $4.13 \mathrm{aA}$ & $2.94 \mathrm{bB}$ \\
\hline $25 \% \mathrm{H}+25 \% \mathrm{M}+25 \% \mathrm{~V}+25 \% \mathrm{C}$ & $4.16 \mathrm{aB}$ & $3.68 \mathrm{aB}$ & $4.118 \mathrm{aA}$ & $4.25 \mathrm{aA}$ & $2.57 \mathrm{bB}$ \\
\hline$* *$ & \multicolumn{5}{|c|}{ Dickson quality index } \\
\hline $25 \% \mathrm{H}+75 \% \mathrm{~V}$ & $0.28 \mathrm{aA}$ & $0.22 \mathrm{bA}$ & $0.23 \mathrm{bA}$ & $0.23 \mathrm{bB}$ & $0.16 \mathrm{cB}$ \\
\hline $50 \% \mathrm{H}+50 \% \mathrm{~V}$ & $0.28 \mathrm{aA}$ & $0.22 \mathrm{bA}$ & $0.19 \mathrm{bB}$ & $0.22 \mathrm{bB}$ & $0.12 \mathrm{cB}$ \\
\hline $75 \% \mathrm{H}+25 \% \mathrm{~V}$ & $0.22 \mathrm{aB}$ & $0.17 \mathrm{bB}$ & $0.16 \mathrm{bB}$ & $0.20 \mathrm{aB}$ & $0.12 \mathrm{cB}$ \\
\hline $25 \% \mathrm{H}+75 \% \mathrm{~V}$ & $0.21 \mathrm{aB}$ & $0.17 \mathrm{aB}$ & $0.16 \mathrm{aB}$ & $0.19 \mathrm{aB}$ & $0.16 \mathrm{aB}$ \\
\hline $50 \% \mathrm{H}+50 \% \mathrm{C}$ & $0.19 \mathrm{aB}$ & $0.18 \mathrm{aB}$ & $0.15 \mathrm{bB}$ & $0.19 \mathrm{aB}$ & $0.13 \mathrm{bB}$ \\
\hline $75 \% \mathrm{H}+25 \% \mathrm{C}$ & $0.21 \mathrm{aB}$ & $0.19 \mathrm{aB}$ & $0.16 \mathrm{bB}$ & $0.17 \mathrm{aB}$ & $0.12 \mathrm{bB}$ \\
\hline $25 \% \mathrm{M}+75 \% \mathrm{~V}$ & $0.29 \mathrm{aA}$ & $0.23 \mathrm{bA}$ & $0.24 \mathrm{bA}$ & $0.29 \mathrm{aA}$ & $0.13 \mathrm{cB}$ \\
\hline $50 \% \mathrm{M}+50 \% \mathrm{~V}$ & $0.32 \mathrm{aA}$ & $0.25 \mathrm{bA}$ & $0.25 \mathrm{bA}$ & $0.28 \mathrm{aA}$ & $0.20 \mathrm{cA}$ \\
\hline $75 \% \mathrm{M}+25 \% \mathrm{~V}$ & $0.30 \mathrm{aA}$ & $0.22 \mathrm{bA}$ & $0.22 \mathrm{bA}$ & $0.26 \mathrm{aA}$ & $0.23 \mathrm{bA}$ \\
\hline $25 \% \mathrm{M}+75 \% \mathrm{C}$ & $0.28 \mathrm{aA}$ & $0.21 \mathrm{bA}$ & $0.22 \mathrm{bA}$ & $0.26 \mathrm{aA}$ & $0.19 \mathrm{bA}$ \\
\hline $50 \% \mathrm{M}+50 \% \mathrm{C}$ & $0.26 \mathrm{aA}$ & $0.24 \mathrm{aA}$ & $0.23 \mathrm{aA}$ & $0.26 \mathrm{aA}$ & $0.19 \mathrm{bA}$ \\
\hline $75 \% M+25 \% C$ & $0.28 \mathrm{aA}$ & $0.23 \mathrm{aA}$ & $0.24 \mathrm{aA}$ & $0.27 \mathrm{aA}$ & $0.26 \mathrm{aA}$ \\
\hline $33.3 \% \mathrm{H}+33.3 \% \mathrm{M}+33.3 \% \mathrm{~V}$ & $0.23 \mathrm{aB}$ & $0.24 \mathrm{aA}$ & $0.24 \mathrm{aA}$ & $0.27 \mathrm{aA}$ & $0.19 \mathrm{bA}$ \\
\hline $33.3 \% \mathrm{H}+33.3 \% \mathrm{M}+33.3 \% \mathrm{C}$ & $0.28 \mathrm{aA}$ & $0.22 \mathrm{bA}$ & $0.21 \mathrm{bA}$ & $0.25 \mathrm{aA}$ & $0.19 \mathrm{bA}$ \\
\hline $25 \% \mathrm{H}+25 \% \mathrm{M}+25 \% \mathrm{~V}+25 \% \mathrm{C}$ & $0.28 \mathrm{aA}$ & $0.22 \mathrm{bA}$ & $0.23 \mathrm{aA}$ & $0.25 \mathrm{aA}$ & $0.19 \mathrm{bA}$ \\
\hline
\end{tabular}

* Equal uppercase letters in the columns and lowercase letters in the lines belong to the same group by the Scott-Knott test at 5\% probability; A1 = agricultural greenhouse; A2 = agricultural greenhouse with thermo-reflective screen under the film; A3 = screenhouse with monofilament screen; $\mathrm{A} 4=$ screenhouse with thermo-reflective screen; A5 = nursery with bacuri straw; $\mathrm{H}=$ earthworm humus; $\mathrm{V}=$ vermiculite $\mathrm{E}=$ cattle manure; $\mathrm{M}=$ cassava stems.

The Dickson quality index is a good seedling quality indicator. It is a balanced formula that includes the relationships of morphological parameters, and the higher the value of this index, the better the seedling quality standard. For the tamarind seedlings, it was verified, in all cultivation environments, that the substrates from $\mathrm{S} 7$ to $\mathrm{S} 15$ were the ones that allowed the plants to reach the highest indexes, proving that the incorporation of cattle manure to the substrates and to those that have mixtures of three or more raw materials, provided better results in the development of tamarind seedlings (Table 5). Hardly a pure material will have all the appropriate characteristics to compose a good substrate and supply the plants' needs, indicating the use of mixtures (Gomes and Silva, 2004).

A5 did not favor the tamarind seedlings as to the Dickson quality index, as they obtained the lowest values in this environment in almost all substrates, except only S4 and S12 substrates (Table 5).

\section{Conclusions}

1. The screened environments and environments with polyethylene films were conducive to the emergence of tamarind seedlings, with a higher percentage of emergence in the greenhouse without the screen under the film. In these environments, all the substrates presented adequate conditions for seedling emergence.

2. The environment covered with native straw was not favorable to the emergence of the tamarind tree. In this environment, substrates containing cattle manure provided the best conditions for seedling emergence.

3. The greenhouses and the screenhouse with the aluminized screen, as well as the substrates containing manure, provided the largest number of leaves, larger plants, and larger diameters.

4. The mixture of cassava stems and cattle manure, as well as the mixture of the three or four tested raw materials, are conducive to the development and accumulation of biomass of tamarind seedlings. 
5. The mixture of humus with vermiculite or cassava stems is not indicated for biomass accumulation in tamarind seedlings.

6. Greenhouses and screenhouses are indicated for the formation of high-quality seedlings.

\section{Acknowledgments}

To the Coordenação de Aperfeiçoamento de Pessoal de Nível Superior (CAPES); to the CNPq Proc. $\mathrm{N}^{\circ}$ $300829 / 2012-4$; to the FUNDECT/PRONEM/CNPq (Emerging Nuclei) Process 59/300.116/2015, 080/201515/2014, and to the FUNDECT/PAPOS/PGAC 2016.

\section{Bibliographic References}

Alves, E.U., Andrade, L.A., Bruno, R.L.A., Vieira, R.M., Cardoso, E.A., 2011. Emergência e crescimento inicial de plântulas de Peltophorum dubium (Spreng.) Taubert sob diferentes substratos. Revista Ciência Agronômica, 42(2), 439447. DOI: https://doi.org/10.1590/S180666902011000200025 .

Araujo, J.R.G., Júnior, M.M.A., Menezes, R.H.N., Martins, M.R., Lemos, R.N.S., Cerqueira, M.C.M., 2006. Efeito do recipiente e ambiente de cultivo sobre o desenvolvimento de mudas de mamoeiro cv. Sunrise Solo. Revista Brasileira de $\begin{array}{lll}\text { Fruticultura, } & 28(3), & 526-529 .\end{array}$ https://doi.org/10.1590/S0100-29452006000300042.

Banzatto, D.A., Kronka, S.N., 2013. Experimentação agrícola, quarta ed. Jaboticabal, FUNEP.

Bezerra Neto, F., Rocha, R.H.C., Rocha, R.C., Negreiros, M.Z., Leitão, M.M.V.B.R., Nunes, G.H.S., 2005. Sombreamento para produção de mudas de alface em alta temperatura e ampla luminosidade. Horticultura Brasileira, 23(1), 133-137. DOI: https://doi.org/10.1590/S0102-05362005000100028.

Cavalcante, L.F., Santos, J.B., Santos, C.J.O., Feitosa Filho, J.C., Lima, E.M., Cavalcante, I.H.L., 2002. Germinação de sementes e crescimento inicial de maracujazeiros irrigados com água salina em diferentes volumes de substrato. Revista Brasileira de Fruticultura, 24(3), 748-751. DOI: http://dx.doi.org/10.1590/S0100-29452002000300047.

Costa, E., Ferreira, A.F.A., Silva, P.N.L., Nardelli, E.M.V., 2012a. Diferentes composições de substratos e ambientes protegidos na formação de mudas de pé-franco de tamarindeiro. Revista Brasileira de Fruticultura, 34(4), 189-1198. DOI: http://dx.doi.org/10.1590/S0100-29452012000400028.

Costa, E., Leal, P.A.M., Mesquita, V.A.G., Sassaqui, A.R., 2011. Efeitos do organosuper ${ }^{\circledR}$ e do ambiente protegido na formação de mudas de mamoeiro. Engenharia Agrícola, 31(1), 41-55. DOI: https://doi.org/10.1590/S010069162011000100005 .

Costa, E., Oliveira, L.C., Santo, T.L.E., Leal, P.A.M., 2012 b. Produção de mudas de baruzeiro em diferentes ambientes protegidos e substratos. Engenharia Agrícola, 32(4), 633-641. DOI: http://dx.doi.org/10.1590/S0100-69162012000400002.
Costa, E., Santos, L.C.R., Vieira, L.C.R., 2009. Produção de mudas de mamoeiro utilizando diferentes substratos, ambientes de cultivo e recipientes. Engenharia agrícola, 29(4), 528-537. DOI: http://dx.doi.org/10.1590/S0100-69162009000400003.

Daniel, O., Vitorino, A.C.T., Alovisi, A.A., Mazzochin, L., Tokura, A.M., Pinheiro, E.R.P., 1997. Aplicação de fósforo em mudas de Acacia mangium willd. Revista Árvore, 21(2), 163168.

Dias, R., Melo, B., 2009. Proporção de material orgânico no substrato artificial para a produção de mudas de cafeeiro em tubetes. Ciência e Agrotecnologia, 33(1), 144-152. DOI: https://doi.org/10.1590/S1413-70542009000100021.

Dias, R., Melo, B., Rufino, M.A., Silveira, D.L., Morais, T.P., Santana, D.G., 2009. Fontes e proporção de material orgânico para a produção de mudas de cafeeiro em tubetes. Ciência e $\begin{array}{llll}\text { Agrotecnologia, } & 33(3), & 758-764 . & \text { DOI: }\end{array}$ https://doi.org/10.1590/S1413-70542009000300014.

Dickson, A., Leaf, A.L., Hosner, J.F., 1960. Quality appraisal of white spruce and white pine seedling stock in nurseries. Forestry Chronicle, 36(1), 10-13. https://pubs.cififc.org/doi/pdf/10.5558/tfc36010-1.

El-Siddig, K., Gunasena, H.P.M., Prasad, B.A., Pushpakumara, D.K.N.G., Ramana, K.V.R., Vijayanand, P., Williams, J.T. 2006. Tamarind (Tamarindus indica L.), in: Williams, J.T., Smith, R.W., Haq, N., Dunsiger, Z., (Eds.). Fruits for the Future 1. Southampton: International Centre for Underutilised Crops, University of Southampton, p. 1-188.

Ferreira, D.F., 2010. SISVAR - Sistema de análise de variância. Versão 5.3. Lavras, UFLA.

Freitas, J.R., Martins, F.C.G., Fernandes, O.R., Saito, S.M.T., Rischel, A.P., Gonçalves, A.N., 1980. Aplicação de matéria orgânica, vermiculita e inoculação de rhizobium spp em sementeira de Erythrina falcata. IPEF, 20, 101-113. https://www.ipef.br/publicacoes/scientia/nr20/cap06.pdf.

Gasparin, E., Araujo, M.M., Avila, A.L., Wielewicki, A.P., 2012. Identificação de substrato adequado para germinação de sementes de Allophylus edulis (a. st.-hil., a. juss. \& cambess.) Radlk. Ciência Florestal, 22(3), 625-630. DOI: https://doi.org/10.5902/198050986628.

Góes, G.B., Dantas, D.J., Araújo, W.B.M., Melo, I.G.C., Mendonça, V., 2011. Utilização de húmus de minhoca como substrato na produção de mudas de tamarindeiro. Revista Verde, 6(4), 125-131.

Gomes, J.M., Silva, A.R., 2004. Os substratos e sua influência na qualidade de mudas, in: Barbosa, J.G., Martinez, H.E.P., Pedrosa, M.W., Sediyama, M.A.N. Nutrição e adubação de plantas cultivadas em substratos. Viçosa, UFV, p. 190-225.

Maguire, J.D., 1962. Speed of germination - aid in selection and evaluation for seedling and vigour. Crop Science, 2, 176-177.

Martins, C.C., Nakagawa, J., Bovi, M.L.A., 1999. Efeito da posição da semente no substrato e no crescimento inicial das plântulas de palmito-vermelho (Euterpe espírito santensis fernandes - Palmae). Revista Brasileira de Sementes, 21(1), 164-173. 
Negreiros, J.R.S., Braga, L.R., Álvares, V.S., Bruckner, C.H., 2005. Diferentes substratos na formação de mudas de mamoeiro do grupo solo. Revista Brasileira de Agrociência, 11(1), 101103. DOI: https://doi.org/10.18539/cast.v11i1.1168.

Negreiros, J.R.S., Braga, L.R., Álvares, V.S., Bruckner, C.H., 2004. Influência de substrato na formação de porta-enxerto de gravioleira (Annona muricata L.). Revista Ciência Agrotecnologia, 28(3), 530-536. DOI: https://doi.org/10.1590/S1413-70542004000300007.

Pereira, P.C., Freitas, R.S., Melo, B., Franzão, A.A., Pereira, A.P., Santana, J.G., 2008. Influência do tamanho de sementes na qualidade de mudas de tamarindeiro. Bioscience Journal, 24(4), 73-79.

Pereira, P.C., Melo, B., Freitas, R.S., Tomaz, M.A., Teixeira, I.R., 2010. Tamanho de recipientes e tipos de substrato na qualidade de mudas de tamarindeiro. Revista Verde, 5(3), 136142.
Santos, L.C.R., Costa, E., Leal, P.A.M., Nardelli, E.M.V., Souza, G.S.A., 2011. Ambientes protegidos e substratos com doses de composto orgânico comercial e solo na formação de mudas de jatobazeiro em Aquidauana-MS. Engenharia Agrícola, 31(2), 249-259. DOI: https://doi.org/10.1590/S010069162011000200005 .

Schallenberger, E., Rebelo, J.Á., Mauch, C.R., Ternes, M., Pegoraro, R.A., 2008. Comportamento de plantas de tomateiros no sistema orgânico de produção em abrigos de cultivo com telas antiinsetos. Revista de Ciências Agroveterinárias, 7(2), 23-29.

Silva, G.B.P., Barros, G.L., Almeida, J.P.N., Procópio, I.J.S., Medeiros, P.V.Q., 2011. Tempo de germinação e desenvolvimento inicial na produção de mudas de Tamarindus indica $\mathrm{L}$. Revista Verde, 6(2), 58-63.

Sousa Neto, O.N., Dias, N.S., Atarassi, R.T., Rebolças, J.R.L., Oliveira, A.M., 2010. Produção de alface hidropônica e microclima de ambiente protegido sob malhas termorefletoras. Revista Caatinga, 24(1), 84-90. 